\title{
Grandeza y fama de don Marcos de Tolosa
}

\author{
FranÇOISE GILBERT \\ Université de Toulouse II-Jean Jaurès
}

Matricularse en el grupo de Marc Vitse para la asignatura de Literatura de Siglo de Oro, en 1986, era todo un reto para quien descubría el planeta de la Universidad en tercer ańo. La licenciatura que ofrecía el entonces prestigioso Departamento de Español de la Universidad de Toulouse-Le Mirail, con programas densos y obras variadas, brindaba a la Literatura de Siglo de Oro una asignatura dedicada al estudio del romancero, de las Novelas Ejemplares y de don Juan Tenorio como eco del de Tirso. Para quien nunca se había confrontado con la hazaña de hacer una explicación de texto ante un grupo de unos treinta compańeros, la cosa ya resultaba impresionante. Pero si a este contexto peliagudo se sumaba que el profesor ante quien se iba a exponer el trabajo era el muy temido Marc Vitse, cuya fama entre los estudiantes rayaba con la leyenda negra, una bien podía considerar que se lanzaba a una aventura extrema.

Las primeras clases con esta figura del hispanismo siglodorista desmintieron algunos rumores, pero confirmaron otros: mirada aguda y maliciosa, cara risueña e irónica, el personaje conjugaba inteligencia deslumbrante con exigencia no negociable. Malhaya el estudiante que llegaba a clase sin preparar el fragmento previsto, o peor, sin leer la obra en su conjunto. Nos recordaba con voz meliflua los derechos y deberes del estudiante — sus responsabilidades, mejor dicho-, y nos susurraba que en un aula oscura y desierta, del todo deshabitada de la gente, y que se llamaba "Biblioteca", se encontraban cosas extrañas pero no peligrosas, como... jlibros! Y que algunos de ellos nunca habían sido hojeados por una mano estudiantil... 
Pero sus escarmientos nunca eran malévolos, sino estimulantes, porque nos retaban, con su ironía iconoclasta, porque nos demostraba que un gran profesor de literatura podía tener su pizca de travesura e irreverencia. Su comprehensión profunda de la literatura de Siglo de Oro resultaba, tanto para el novato como para el investigador provecto, inaudita. $\mathrm{Su}$ exigencia de rigor y trabajo, extrema. Su profesionalismo, en fin, en las clases de Agrégation sobre el teatro de Lope y Tirso, quintaesencia de la teoría magistral de su Éléments pour une théorie du théâtre espagnol $d u$ XVIIe siècle. Y cuando, algunos años más tarde, se atrevió una a redactar la suya bajo su dirección, pudo comprobar que su rigor funcionaba como el mejor de los alicientes, aunque adoptando la forma de pacientes y escarlatas correcciones marginales, regularmente mandadas. Pero en su afán de mejorar lo escrito, y penosamente integrado de correcciones anteriores por la doctoranda, pudo ocurrir que su ojo de lince a veces no detectara que, de vez en cuando, se iba autocorrigiendo. Para terminar, cifra y compendio de su aprehensión humilde y un tanto ascética de la labor investigadora, este secreto que algún día compartió conmigo: "El trabajo es lo único que nunca te decepciona”... 